\title{
CIÊNCIANATURA
}

\section{Analysis of cuticular chemical profiles of Latrodectus geometricus (Araneae: Theridiidae) females and juveniles using GC $\times$ GC/qMS}

Análise do perfil químico cuticular de fêmeas e imaturos de Latrodectus geometricus (Araneae: Theridiidae) usando $\mathrm{GC} \times \mathrm{GC} / \mathrm{qMS}$

Ingrid de Carvalho Guimarães ${ }^{1,2^{*}}$, Claudia Andrea Lima Cardoso ${ }^{1}$, Elina Bastos Caramão ${ }^{3,4}$, Jaderson Kleveston Schneider ${ }^{3}$ and William Fernando Antonialli Junior ${ }^{1,2}$

${ }^{1}$ Programa de Pós-graduação em Recursos Naturais, Universidade Estadual de Mato Grosso do Sul, Dourados, Mato Grosso do Sul, Brazil ${ }^{2}$ Laboratório de Ecologia Comportamental, Centro de Estudos em Recursos Naturais, Universidade Estadual de Mato Grosso do Sul,

Dourados, Brazil

${ }^{3}$ Instituto de Química, Universidade Federal do Rio Grande do Sul, Porto Alegre, Brazil

${ }^{4}$ Departamento de Bioquímica Industrial, Universidade Tiradentes, Aracaju, Brazil

\begin{abstract}
Communication in spiders can occur by several mechanisms, especially chemical cues, and cuticular hydrocarbons (CHCs) play an important role in intraspecific recognition. Several techniques have been used to evaluate CHCs in spiders. Here, rapid-scanning two-dimensional gas chromatography with quadrupole mass spectrometry $(G C \times G C / q M S)$ was employed to assess the CHCs of L. geometricus females and juveniles of different ages. Samples of adult females' cephalothorax, abdomen and legs, were used to assess whether there is variation in CHCs between body parts. To assess whether there is variation between ages, juveniles of 5 and 20 days post-emergence were evaluated. The results demonstrate that there is variation in CHCs of different body parts of females, with abdomen presenting greater number of compounds, as well as between adults and juveniles. Branched alkanes represented the majority of compounds in all samples, followed by linear alkanes. Alkenes were only present in adult's abdomen and cephalothorax. The compounds 10-methyloctacosane and 14-methyloctacosane; and 10-methyltriacontane and 14-methyltriacontane showed the same retention time in ${ }^{1} D$ and were separated in ${ }^{2} D$. According to the results, rapid-scanning $G C \times G C / q M S$ can be considered a reliable technique, since it was possible to identify the spider's CHCs, and detect and separate two cases of chromatographic coelution.

Keywords: Gas chromatography. Spider. Communication. Mass spectrometry.
\end{abstract}

\section{Resumo}

A comunicação em aranhas pode ocorrer por vários mecanismos, especialmente sinais químicos, e os hidrocarbonetos cuticulares (CHCs) desempenham papel fundamental no reconhecimento intraespecifico. Várias técnicas têm sido utilizadas para avaliar os CHCs em aranhas. Aqui, a Cromatografia bidimensional de varredura rápida com espectrometria de massa quadrupolo foi empregada para avaliar o perfil de CHCs de fêmeas de L. geometricus e imaturos de diferentes idades. Amostras do cefalotórax, abdome e pernas de fêmeas foram usadas para avaliar se há variação em CHCs entre as partes. Para avaliar se há variação entre idades, foram usados imaturos de 5 e 20 dias pós-emergência. Os resultados demonstram que há variação em CHCs de diferentes partes do corpo, com abdome apresentando o maior número de compostos, bem como entre adultos e imaturos. Alcanos ramificados representaram a maioria dos compostos em todas as amostras, seguidos por alcanos lineares. Alcenos só estavam presentes no abdome e cefalotórax das adultas. Os compostos 10-metiloctacosano e 14-metiloctacosano; e 10-metiltriacontano e 14-metiltriacontano tiveram o mesmo tempo de retenção em ${ }^{l} D$ e foram separados em ${ }^{2} D$. De acordo com os resultados, a técnica pode ser considerada confiável, já que foi possível identificar os CHCs da aranha, e detectar e separar dois casos de coeluição cromatográfica.

Palavras-chave: Cromatografia gasosa. Aranha. Comunicação. Espetrometria de massas. 


\section{Introduction}

Communication in spiders can occur by several mechanisms, such as visual, sound and chemical cues. Pheromones play an important role as they serve as signals for reproduction, recognition of conspecifics and among relatives, warning of danger, territory marking, signs of dominance, state of health and even reproductive status (ANDRADE; KASUMOVIC, 2005; BARUFFALDI; ANDRADE, 2015; JOHANSSON; JONES, 2007; PROUVOST et al., 1999; STOLTZ et al., 2007; UETZ; ROBERTS, 2002; UHL, 2013; WYATT, 2003).

Some non-volatile compounds, present on spider's body or silk can also act as pheromones, being called contact pheromones. Cuticular Hydrocarbons (CHCs), are types of contact pheromones related to intraspecific recognition, male choice and courtship behavior, changes in pheromone emissions by mated females and mediation of aggressive behavior (BARUFFALDI; ANDRADE, 2015; BARUFFALDI; COSTA, 2010, 2014; GASKETT, 2007; GRINSTED et al., 2011; GUIMARÃES et al., 2016; POURIÉ; TRABALON, 1999; POURIÉ et al., 2005; PROUVOST et al., 1999; TRABALON; ASSI-BESSÉKON, 2008; TRABALON et al., 1996, 1997).

Several techniques have been used to evaluate the cuticular chemical composition in spiders and other arthropod's species, especially in social insects. Fourier Transformed Infrared Photoacoustic Spectroscopy (FTIR-PAS) has been used to assess qualitative variations in these cuticular chemical compounds. This technique has been proven to be reliable for assessing intraspecific variation of cuticular chemical composition in ants, social wasps and spiders (ANTONIALLI-JUNIOR et al., 2007, 2008; GUIMARÃES et al., 2016; NEVES et al., 2012, 2013; TORRES et al., 2014). The most usual techniques employed in qualitative and quantitative evaluation of cuticular composition are Gas Chromatography with Flame Ionization Detection (GC-FID) (POURIÉ; TRABALON, 1999, 2001; POURIÉ et al., 2005; TRABALON, 2011; TRABALON et al., 1996, 1997, 1998) or Gas Chromatography coupled to Mass Spectrometric detection (GC-MS) (GRINSTED et al., 2011; GUIMARÃES et al., 2016; PROUVOST et al., 1999; TRABALON et al., 1996, 2005).

Considerable research has been dedicated to the combination of independent techniques with the aim of strengthening the resolving power of chromatographic systems. The satisfactory separation of a complex sample requires a higher peak capacity, being indicated the use of comprehensive two-dimensional gas chromatography (GC $\times \mathrm{GC})$, a relatively new technique (MONDELLO et al., 2008). In GC $\times$ GC, two orthogonal mechanisms are used to separate the constituents of the sample within a single analysis, based on the application of two GC columns with different stationary phases connected in series, with a transfer device, defined as modulator. The function of the modulator is to isolate, re-concentrate, and introduce small portions of the primary column effluent onto a secondary column, continuously. The time required to complete this process is defined as the modulation period (MONDELLO et al., 2008).

Complex mixtures can present coelution of compounds that might not be detected by the usual techniques, thus $\mathrm{GC} \times \mathrm{GC}$ can provide satisfactory analytical results for the analysis of many complex samples, since it provides better separation and identification of compound classes (ISAACMAN et al., 2012). Recently, it has been used to analyze cadaveric Volatile Organic Compounds (VOCs), which are used to establish the Post-Mortem Interval (PMI) in medico-legal investigations (BALA; SHARMA, 2016; DEKEIRSSCHIETER et al., 2012). This technique has also been used to identify the sexual pheromone components of the defoliator insect Ectropis grisescens which, according to the authors, could be useful in developing alternative management tools for the pest (MA et al., 2016). Ralston-Hooper et al. (2008) used GCxGC to compare metabolite profiles of an invertebrate species and established that the technique was able to detect differences, which could be helpful in ecotoxicological studies. However, to our knowledge, this is the first study employing this technique to assess cuticular chemical composition.

The species studied here, Latrodectus geometricus, presents an hourglass in the ventral face, usually orange, and is known as "hourglass spider" or "brown widow spider". These spiders are widespread across all continents except in polar regions, and are considered synanthropic (COSTELLO; DAANE, 1998; GARB et al., 2004; LOTZ, 1994; MÜLLER, 1993). The species first description was in 1841, however, its place of origin is uncertain because by that time its occurrence had already been documented in Africa and South America (GARB et al., 2004). Despite possessing one of the venoms with higher toxicity within the genus (MCCRONE, 1964; VINCENT et al., 2008) these spiders are not aggressive and accidents usually happen when they are compressed. Thus, although they are cosmopolitan, studies with this species are scarce, probably because there are few cases of accidents with humans (LEVI et al., 2001). Few studies focus on aspects of basic biology and natural history of this species, such as Liu et al. (2009) regarding embryonic development, Segoli et al. (2008) on sexual cannibalism, Guimarães et al. (2012) regarding the influence of aggregation behavior on life expectancy of juveniles and Guimarães et al. (2016) studying the role of cuticular compounds as mediators of interactions between adults and juveniles. Considering that cuticular chemical profiles are a complex mixture and, as such, might present coelution of compounds that may not be resolved by the most common techniques, in this study rapid-scanning $\mathrm{GC} \times \mathrm{GC} / \mathrm{qMS}$ was employed to assess the cuticular chemical composition of L. geometricus females' body parts and juveniles of different ages. 


\section{Material and Methods}

Adult females of L. geometricus were collected in Dourados, State of Mato Grosso do Sul. Eggsacs were used for species identification because they have a peculiar conformation, spherical and covered with conical protuberances, which, according to Abalos (1962), facilitates their identification. Females with their eggsacs were individually transferred to laboratory in 500 $\mathrm{ml}$ containers. Relative humidity was controlled by moistened cotton placed at the bottom of each container, as a way to preserve silk elasticity (EDMONDS; VOLLRATH, 1992; WORK; MOROSOFF, 1982; WORK; YOUNG, 1987). Spiders were fed with Tenebrio molitor larvae offered twice a week

\section{$\mathrm{GC} \times \mathrm{GC} / \mathrm{qMS}$ analysis}

In order to assess whether there is variation in cuticular chemical composition between the different body parts of $L$. geometricus adult females, samples of cephalothorax, abdomen and legs were evaluated by GC $\times$ GC/qMS. To assess whether the technique can detect cuticular composition variations between juveniles of different ages as found by GUIMARÃES et al. (2016), juveniles of 5 and 20 days post-emergence were evaluated.

The cuticular constituents of each sample were extracted by immersing each sample in a glass container with $1 \mathrm{ml}$ hexane (Tedia, HPLC grade) for 10 minutes, using ultrasonic bath. Then, the solvent was dried under fume hood and each extract was solubilized in $200 \mu \mathrm{l}$ of hexane for chromatographic analysis. Samples were analyzed in triplicate, with coefficient of variation of less than $5 \%$.

$\mathrm{GC} \times \mathrm{GC} / \mathrm{qMS}$ analyses were carried out on a Shimadzu GC $\times \mathrm{GC} / \mathrm{qMS}$ system consisting of a GC2010 gas chromatograph and a QP2010 plus quadrupole mass spectrometer (Shimadzu Corp., TYO, Japan). The system was provided with a loop-type modulator (Zoex Corp., TX, USA) cooled with liquid nitrogen and with the hot jet pulse time set at $500 \mathrm{~ms}\left(300^{\circ} \mathrm{C}\right)$ with modulation times of $5 \mathrm{~s}$. Initial temperature of the ${ }^{1} \mathrm{D}$ column was $80^{\circ} \mathrm{C}$ reaching $280^{\circ} \mathrm{C}$ at a rate of $4^{\circ} \mathrm{C}$ min ${ }^{-1}$, remaining at this temperature for $15 \mathrm{~min}$, totaling $65 \mathrm{~min}$. Carrier gas helium $(99.999 \%)$ at a flow rate of $1 \mathrm{~mL} \mathrm{~min}^{-1} ; 1 \mu \mathrm{L}$ of injection volume, split ratio (1:20). The ${ }^{2} \mathrm{D}$ column was a DB-17 (50\% phenyl methylpolysiloxane, Agilent Technologies, CA, USA) analytical column $(2.15 \mathrm{~m} \times 0.18 \mathrm{~mm} \times 0.18 \mu \mathrm{m})$ and the analyses conditions were the same as above described for the ${ }^{1} \mathrm{D}$. The temperatures of the injector, transfer line and detector were maintained at $280{ }^{\circ} \mathrm{C}$. The MS scan parameters included electron impact ionization voltage of $70 \mathrm{eV}$, a mass range of 50 to 650 Daltons and a scan interval of $0.5 \mathrm{~s}$. The hexane was analyzed in the same conditions of samples.

The retention index (RI) was calculated employing a linear $\mathrm{C}_{7}-\mathrm{C}_{40}$ alkane mixture analyzed using identical $\mathrm{GC} \times \mathrm{GC} / \mathrm{qMS}$ conditions. The RI was calculated for each compound of the sample according to the equation below (1). The RI values obtained by linear equation were compared with the values of literature.

$$
\mathrm{RI}=100 x\left[n+(N-n) \frac{\operatorname{tr}(\text { unknow })-\operatorname{tr}(n)}{\operatorname{tr}(N)-\operatorname{tr}(n)}\right]
$$

Where RI is the Krafts index, $\mathbf{n}$ is the number of carbon atoms of the lower n-alkanes, $\mathbf{N}$ is the number of carbon atoms of the higher n-alkanes and tr is the retention time.

Data acquired were processed using GC Image software (2.2b1; Zoex Corp., TX, USA). Compounds were tentatively identified by comparing their RI to those reported in literature (BONAVITA-COUGOURDAN et al., 1991; BROWN et al., 1991; MICHELUTTI et al., 2017) and the mass spectra obtained were compared with NIST21 and WILEY229 databases. An Identity Spectrum Match factor above 800 resulting from the NIST and WILEY was determined to be acceptable for positive identification.

\section{Results}

The analyses of the samples detected 50 peaks in total, from heptadecane to 17-, 13-, 15-, 11-methylpentatriacontane (Table 1). Forty-one peaks were present in abdomen samples, 22 in cephalothorax, 13 in legs, and 8 in the juvenile's samples of both ages (Table 1). All peaks present in adult's cephalothorax and legs, and 20 days post-emergence juvenile's samples were identified, representing $100 \%$ of relative abundance, as well as 38 peaks present in adult's abdomen samples and 7 in juveniles of 5 days post-emergence, representing $99 \%$ and $80.5 \%$ respectively (Table 1 ). 


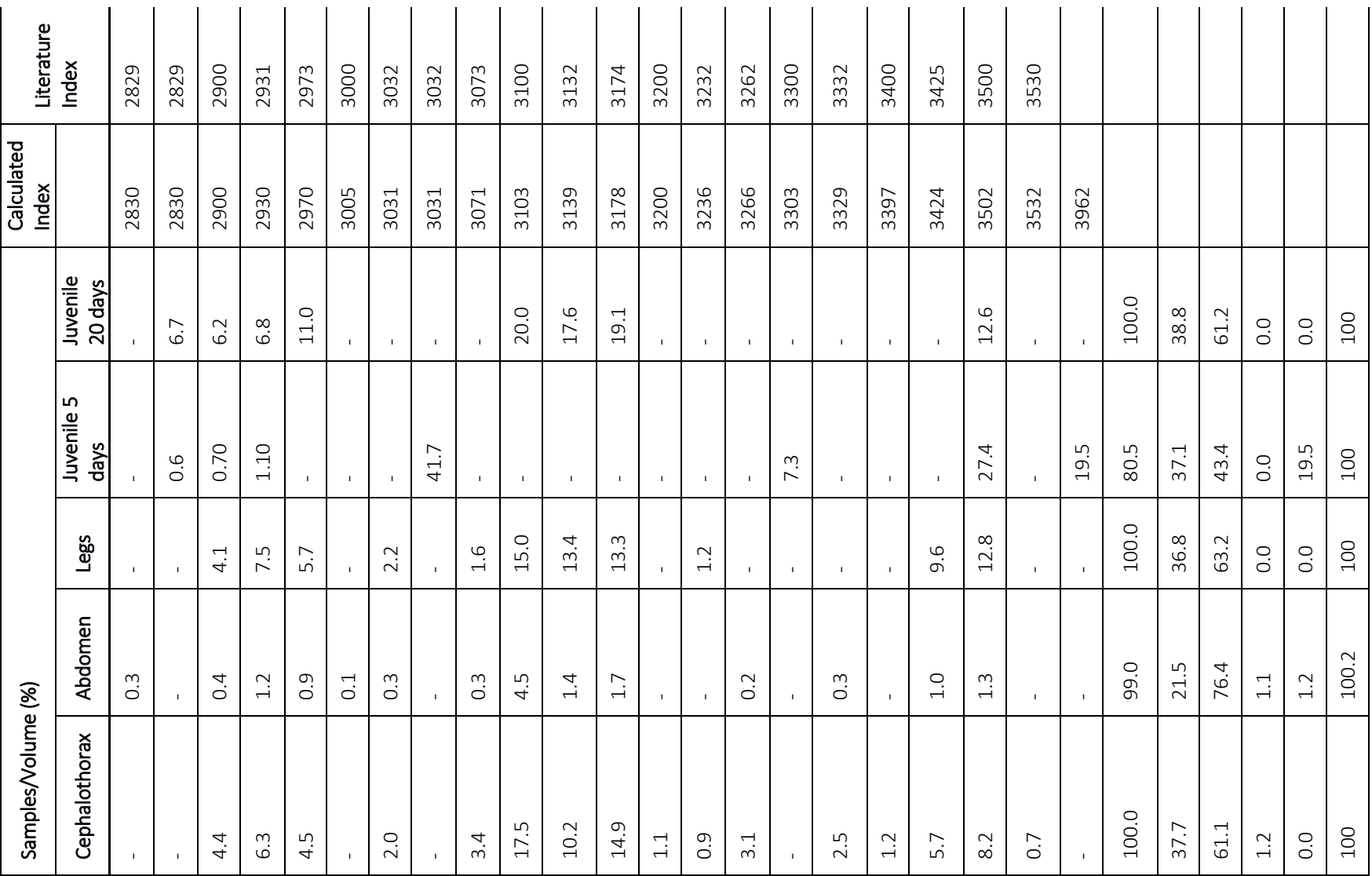

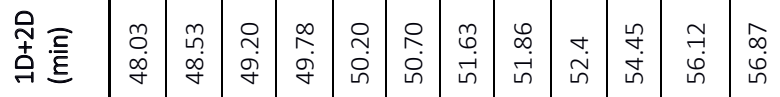

\begin{tabular}{|c|c|c|c|c|c|c|c|c|c|c|c|c|c|c|c|c|c|c|c|c|c|c|}
\hline$\stackrel{n}{a}$ & & $\underset{\rightarrow}{\tilde{T}}$ & $\stackrel{+}{\stackrel{+}{i}}$ & $\underset{i}{\stackrel{i}{i}}$ & $\underset{\stackrel{+}{+}}{\stackrel{+}{*}}$ & $\underset{i}{A}$ & $\underset{\mathrm{i}}{\mathrm{i}}$ & $\stackrel{\vec{S}}{\text { in }}$ & $\underset{\sim}{\infty}$ & $\stackrel{\overrightarrow{\mathrm{\sigma}}}{\mathrm{i}}$ & & $\underset{\rightarrow}{\sim}$ & $\underset{\sim}{\tilde{H}}$ & 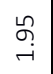 & $\stackrel{m}{i}$ & $\underset{f}{\stackrel{f}{\dot{f}}}$ & $\underset{\mathrm{i}}{\stackrel{d}{\mathrm{i}}}$ & $\stackrel{\text { I }}{i}$ & $\stackrel{\text { }}{\sim}$ & 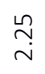 & $\stackrel{\infty}{\sim}$ & \\
\hline & & $\dot{q}$ & $\begin{array}{l}8 \\
\stackrel{0}{\circ} \\
\stackrel{0}{\sigma}\end{array}$ & 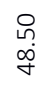 & ச் & $\stackrel{n}{n}$ & \begin{tabular}{|l}
0 \\
0 \\
0 \\
in
\end{tabular} & & & & & 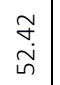 & \begin{tabular}{l}
$\stackrel{n}{\sim}$ \\
\multirow{i}{n}{}
\end{tabular} & 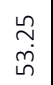 & $\begin{array}{l}\infty \\
\infty \\
\\
\end{array}$ & $\begin{array}{l}\stackrel{\sim}{0} \\
\stackrel{n}{n}\end{array}$ & $\begin{array}{l}\mathcal{F} \\
\text { \& }\end{array}$ & 孞 & $\begin{array}{l}\infty \\
\text { o. } \\
i n\end{array}$ & & $\stackrel{m}{n} \underset{n}{n}$ & \\
\hline
\end{tabular}

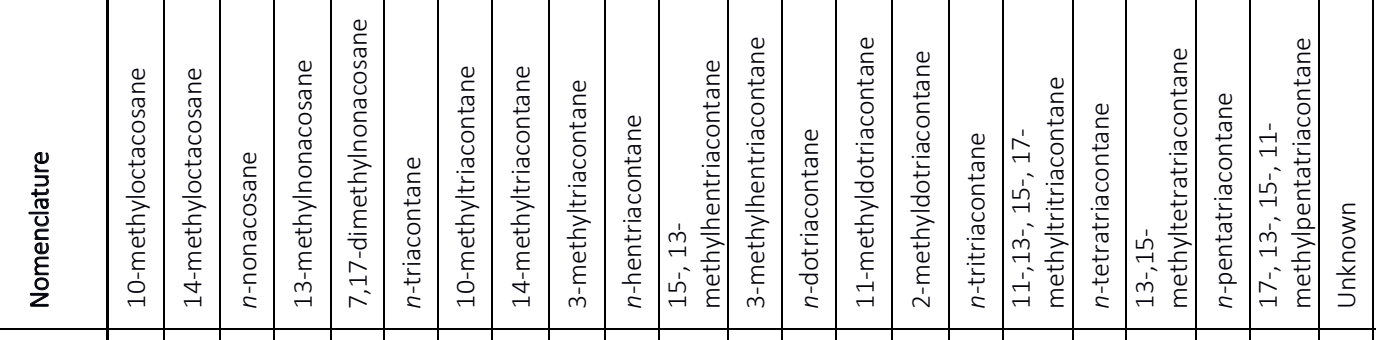

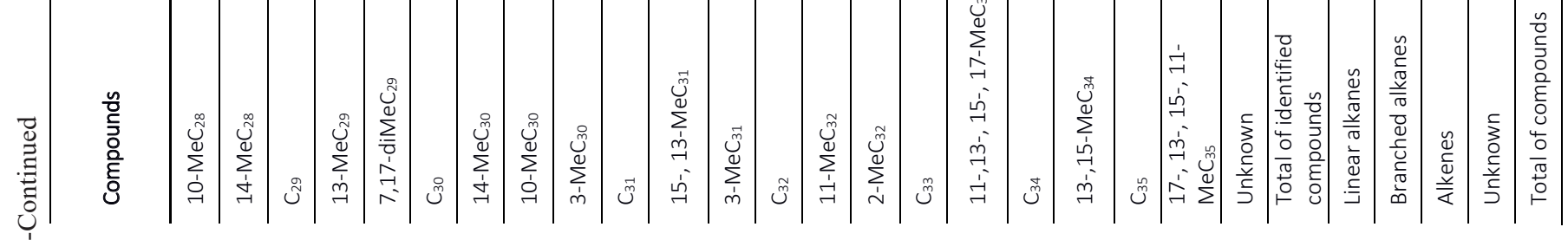


For all samples, branched alkanes represented the majority of compounds with $61.1 \%$ of relative abundance in adult's cephalothorax samples, $76.4 \%$ in abdomen, $63.2 \%$ in legs, $43.4 \%$ in juveniles of 5 days post-emergence and $61.2 \%$ in juveniles of 20 days post-emergence, while linear alkanes represented 37.7\%, 21.5\%, 36.8\%, 37.1\% and 38.8\% respectively. Alkenes were only present in adult's cephalothorax and abdomen samples (Figure 1). The chromatograms for all types of samples are shown in Figures 2-6.

Figure 1 - Percentage abundance of Linear alkanes, Branched alkanes and Alkenes from cuticular chemical profiles of adults' body parts and juveniles of Latrodectus geometricus

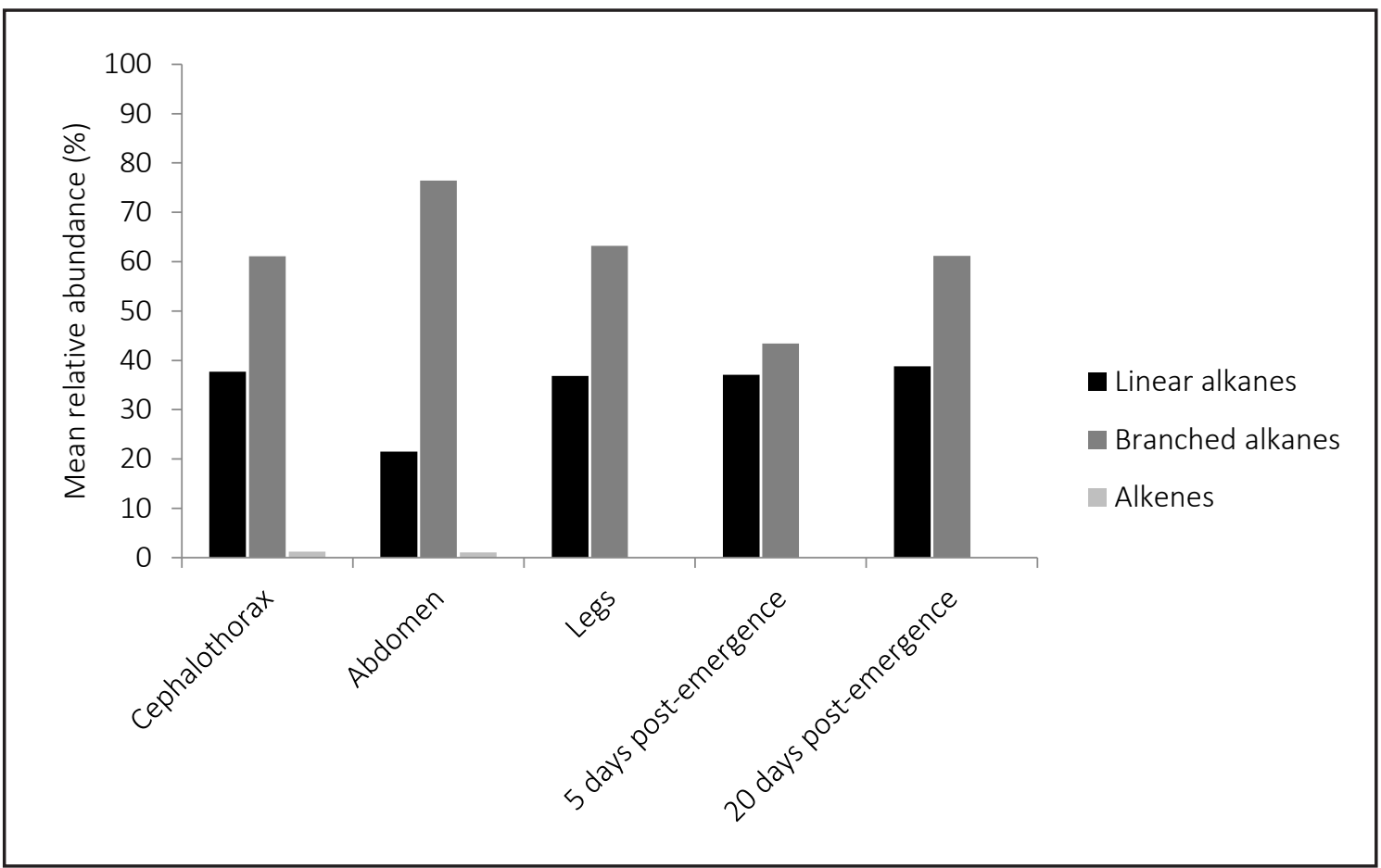

Figure 2 Bi-dimensional chromatogram of the cuticular chemical composition of cephalotorax of Latrodectus geometricus adult females

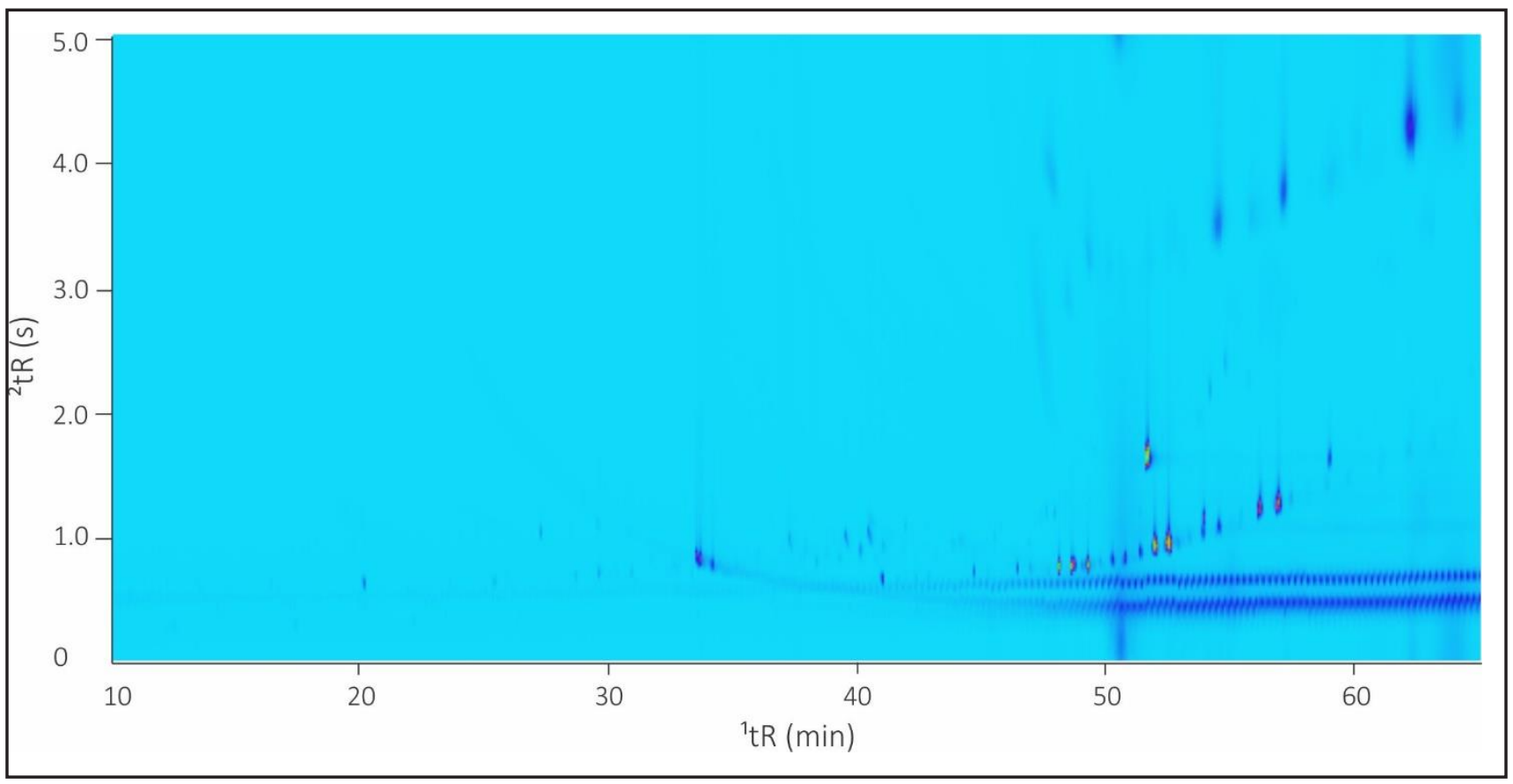


Figure $3 \mathrm{Bi}$-dimensional chromatogram of the cuticular chemical composition of abdomen of Latrodectus geometricus adult females

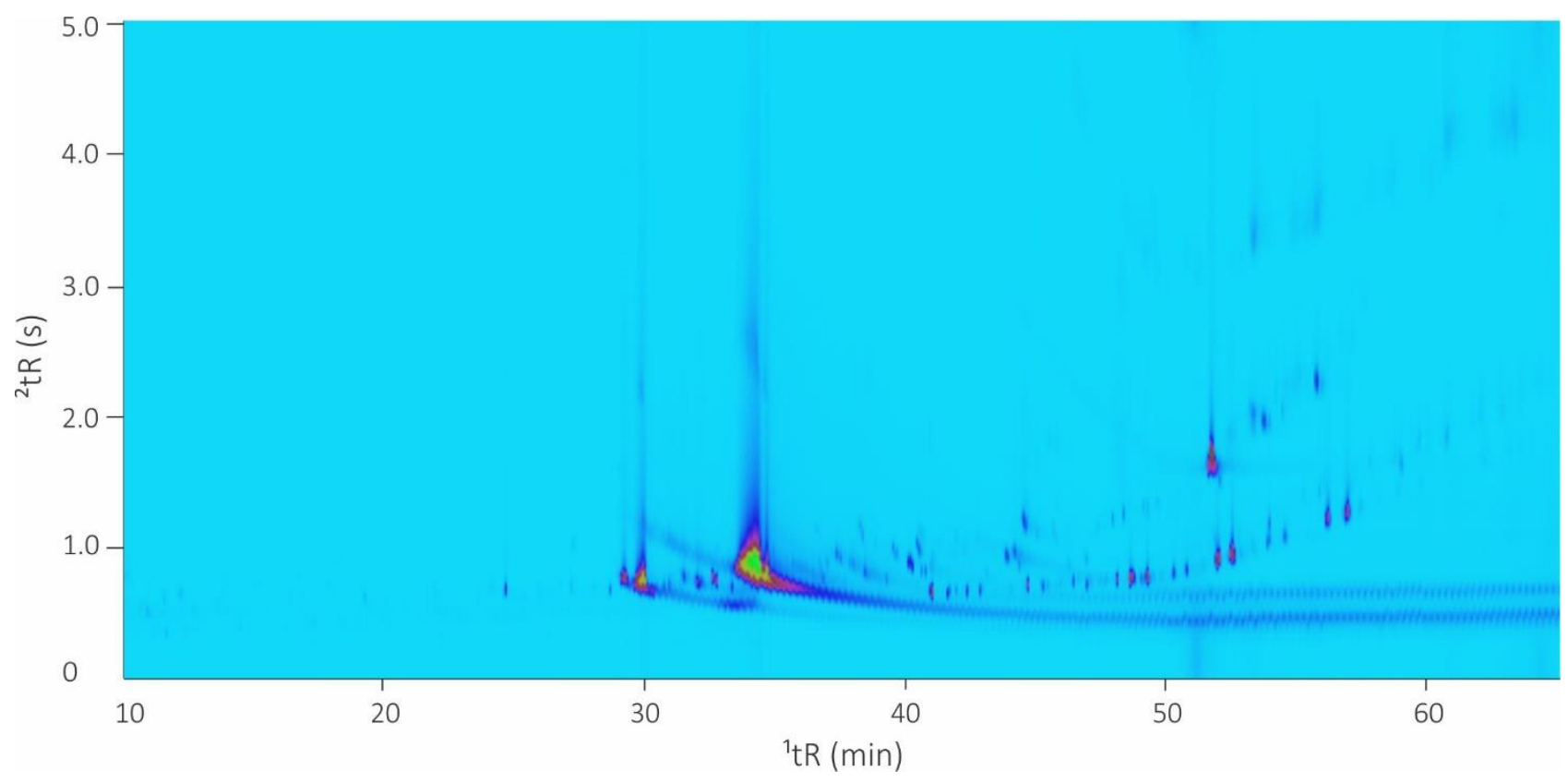

Figure 4 Bi-dimensional chromatogram of the cuticular chemical composition of legs of Latrodectus geometricus adult females

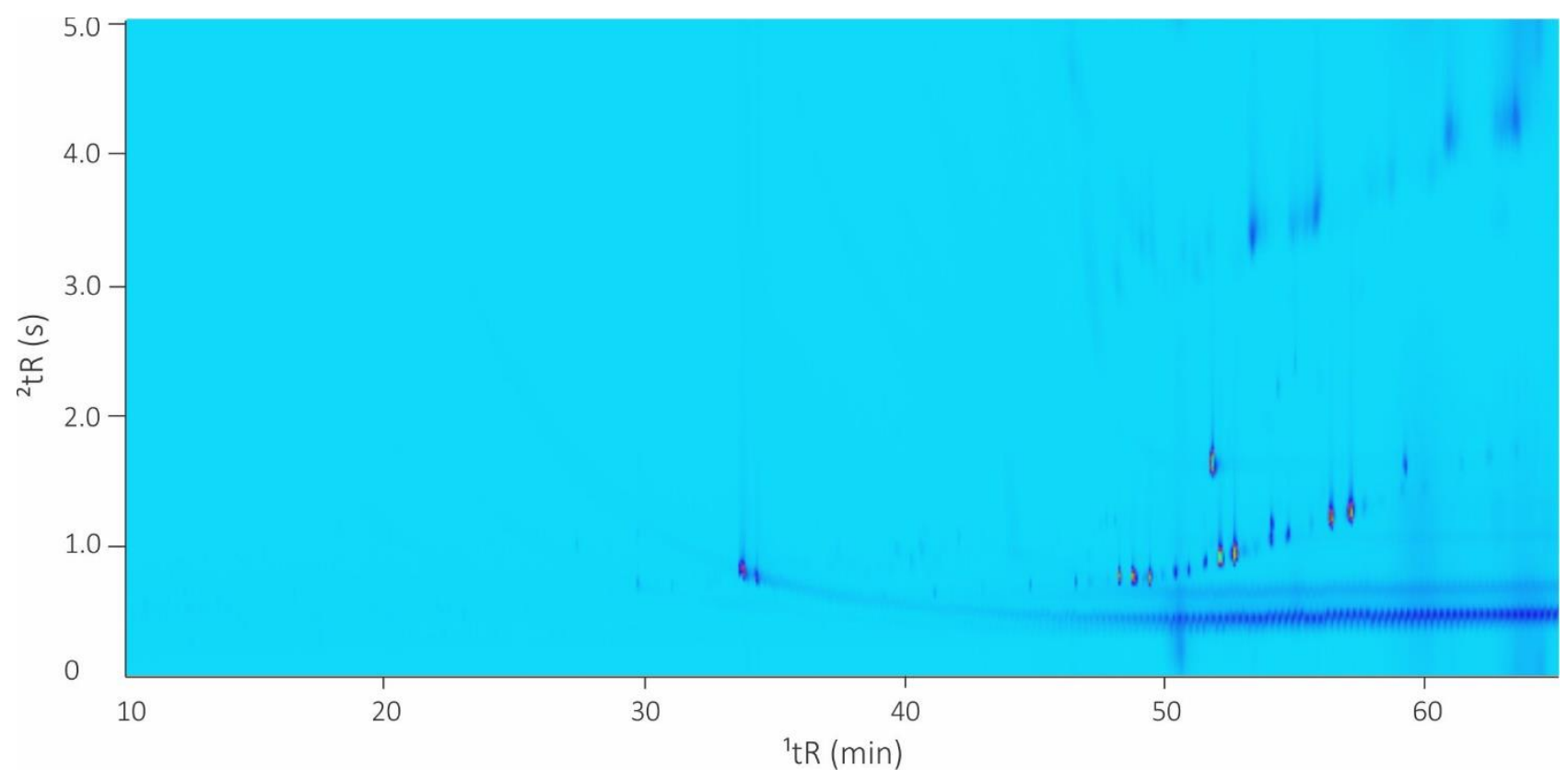

It was found two cases of compounds that seemed to co-elute in the first dimension and were completely separated in the ${ }^{2} \mathrm{D}$ (Table 1). It is possible to observe two methyl alkanes that had the same ${ }^{1} t_{R} 46.83$ min and presented the following retention times in the ${ }^{2} \mathrm{D}$ : 10 -methyloctacosane $\left({ }^{2} \mathrm{t}_{\mathrm{R}} 1.68 \mathrm{~s}\right)$ and 14-methyloctacosane $\left({ }^{2} \mathrm{t}_{\mathrm{R}} 1.92 \mathrm{~s}\right)$; and the separation of two compounds that elute at ${ }^{1} \mathrm{t}_{\mathrm{R}} 50.67 \mathrm{~min}$ and presented the following retention times in the ${ }^{2} \mathrm{D}$ : 10 -methyltriacontane $\left({ }^{2} \mathrm{t}_{\mathrm{R}} 1.77 \mathrm{~s}\right)$ and 14-methyltriacontane $\left({ }^{2} \mathrm{t}_{\mathrm{R}} 2.01 \mathrm{~s}\right)$.

In adult's cephalothorax, the major compounds included hentriacontane, 3-methylhentriacontane, 15-,13-methylhentriacontane and pentatriacontane. In adult's legs, the major compounds were hentriacontane, 15-, 13-methylhentriacontane, 3-methylhentriacontane and pentatriacontane, while in abdomen the major compound was 2-methylheneicosane. In juveniles of 5 days post-emergence the major compounds were 10-methyltriacontane and pentatriacontane, while in juveniles of 20 days post-emergence the major compounds were hentriacontane, 3-methylhentriacontane and 15-, 13-methylhentriacontane (Table 1). 
Figure 5 Bi-dimensional chromatogram of the cuticular chemical composition of Latrodectus geometricus juveniles of 5 days

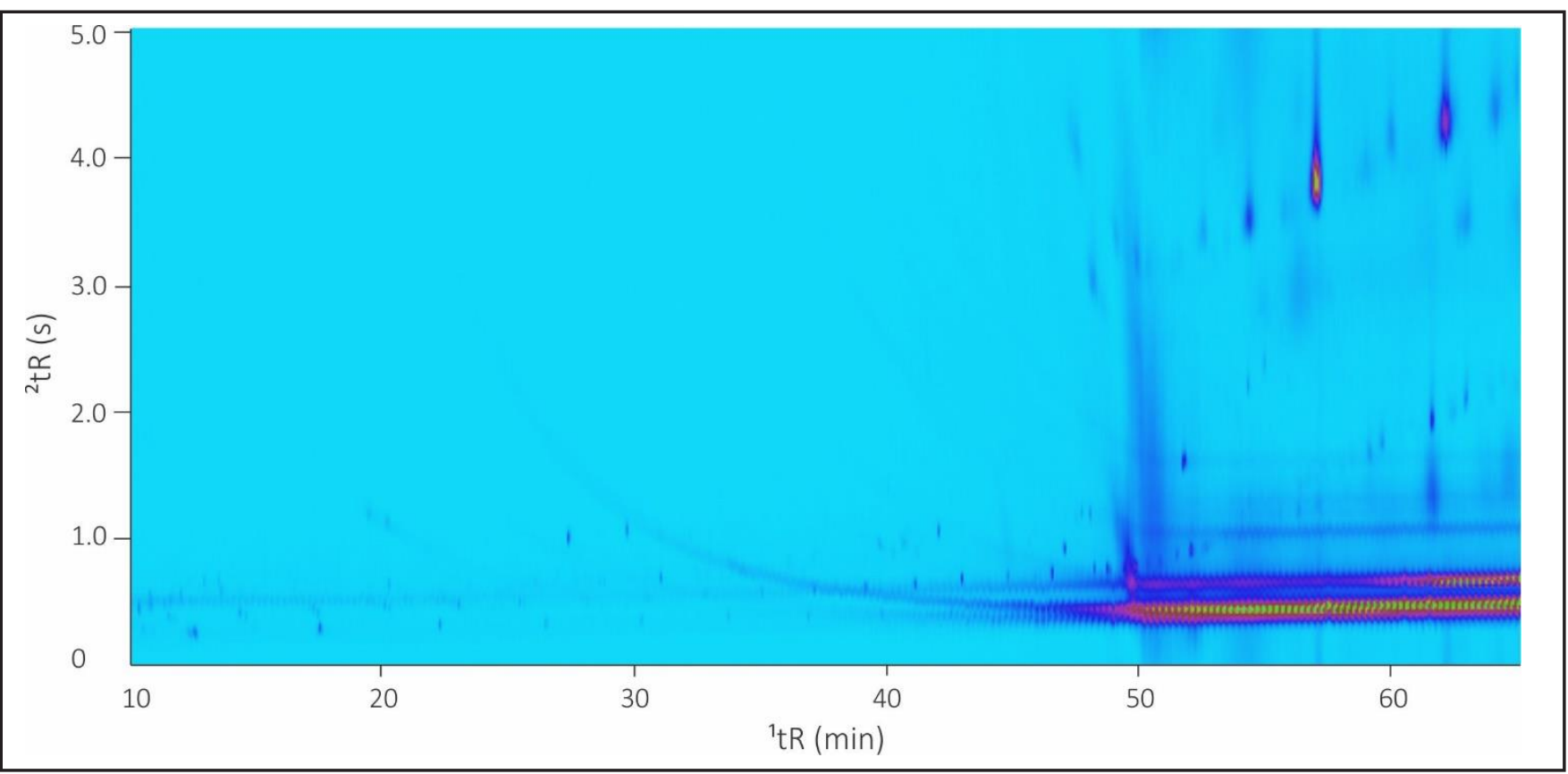

Figure 6 Bi-dimensional chromatogram of the cuticular chemical composition of Latrodectus geometricus juveniles of 20 days

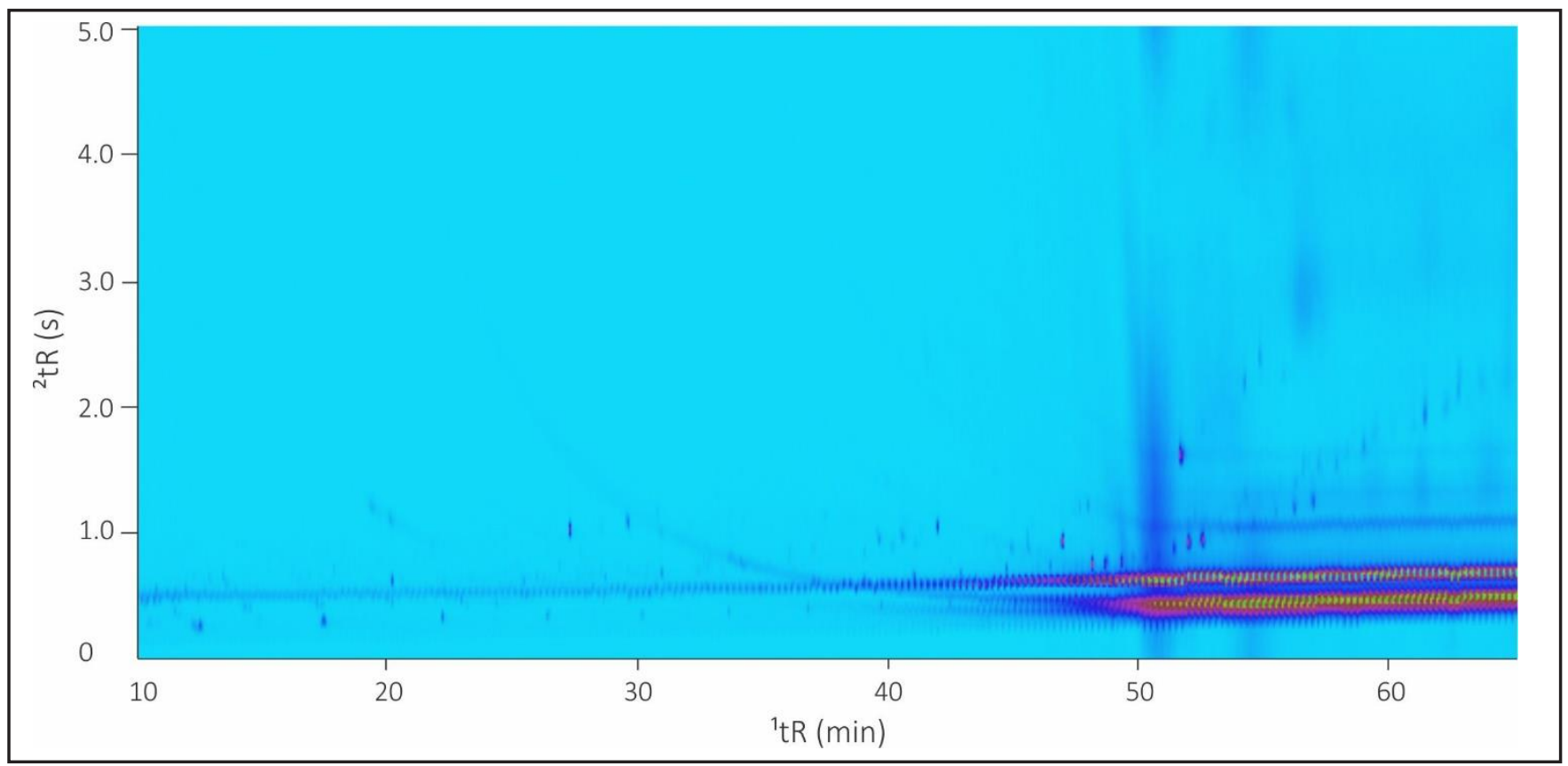

\section{Discussion}

Comparing the variation in cuticular chemical compounds between L. geometricus adult's body parts it is possible to notice that the abdomen has greater number of compounds in relation to cephalothorax and legs. Guimarães et al. (2016) assessing the cuticular chemical profile of the same species by FTIR-PAS found that the readings of the compounds from all body parts have the same peaks, however in the abdomen these peaks showed greater intensity. These results may be explained by the fact that FTIR-PAS only detects vibrations of molecular chemical groups, and as such, it is capable of identifying and distinguishing molecular radicals and some types of chemical bonds, which could explain the presence of the same peaks in all body parts, despite the qualitative differences found by $\mathrm{GC} \times \mathrm{GC} / \mathrm{qMS}$, since some of the peaks might be composed of the same chemical groups. 
The fact that females' abdomen present greater number of compounds than the other body parts can be related to the presence of spinnerets, organs responsible for producing the silk threads, and ovaries. Some specific substances, called sex pheromones appear to be strongly associated with the female's silk, since it can trigger male's courtship behavior (FOELIX, 2011). Indeed, experiments demonstrate that sealing the female's spinnerets with wax, thus preventing the deposition of silk on the ground, causes males to fail to court (DONDALE; HEDGEKAR, 1973). Thus, it is possible that during silk manipulation, either during courtship behavior or web production, some of the silk compounds stay adhered to the abdomen's cuticle. In addition, males' ability to discriminate between silk threads from virgin and mated females has been reported in many studies (e.g. ANAVA; LUBIN, 1993; ANDRADE; KASUMOVIC, 2005; BARUFFALDI; COSTA, 2010; ROBERTS; UETZ, 2005), supporting the hypothesis that the physiological stage of ovaries present on the abdomen of females might influence on CHC composition. In the juveniles cases the lower number of compounds relative to all body parts of the adults is likely because their chemical signatures are not complete yet, since they undergo several molts until reaching adulthood. Indeed, it is well known that cuticular composition changes as the juveniles develop, especially around the period of dispersion (GRINSTED et al., 2011; TRABALON et al., 1996).

Table 1 show the separation of compounds that seemed to co-elute in the first dimension and were completely separated in the ${ }^{2} \mathrm{D}$. The separation of two compounds that elute at ${ }^{1} t_{R} 50.67 \mathrm{~min}$ and presented the following retention times in the ${ }^{2} \mathrm{D}$ : 10 -methyltriacontane $\left({ }^{2} \mathrm{t}_{\mathrm{R}} 1.77 \mathrm{~s}\right)$ and 14-methyltriacontane $\left({ }^{2} \mathrm{t}_{\mathrm{R}} 2.01 \mathrm{~s}\right)$ with distinct molecular mass. It is possible to observe two compounds that had the same ${ }^{1} t_{R} 46.83$ min and presented the following retention times in the ${ }^{2} \mathrm{D}$ : 10 -methyloctacosane $\left({ }^{2} \mathrm{t}_{\mathrm{R}} 1.68 \mathrm{~s}\right)$ and 14-methyloctacosane $\left({ }^{2} \mathrm{t}_{\mathrm{R}} 1.92 \mathrm{~s}\right)$ and the mass spectra of these compounds show base peak and molecular ion characteristic of both compounds. This type of situation is an example of coelution and demonstrates the selectivity and peak capacity added to the system as a different interaction mechanism among analytes and stationary phase provided by the second dimension column. The mass spectra deconvolution software may be employed and may provide separation among two or more compounds (ÖZÇIMEN; KARAOSMANOĞLU, 2004). This can represent a great implication on the results presented on studies that assessed cuticular chemical composition in both spiders and other arthropods, since the number of compounds described can be greater than the ones found by the usual chromatographic techniques. In this sense, species that presented a relatively large number of cuticular compounds in previous studies, such as the spider Anelosimus eximius and the paper wasp Mischocyttarus consimilis, might actually have an even greater number of compounds (MICHELUTTI et al., 2017; PASQUET et al., 1997).

$\mathrm{GC} \times \mathrm{GC} / \mathrm{qMS}$ analysis of the samples detected 50 peaks in total, from heptadecane to 17-, 13-, 15-, 11-methylpentatriacontane with branched alkanes representing the majority of compounds in all samples, similar to the cuticular chemical profile of the subsocial spider Stegodyphus lineatus, assessed by GC-MS, which was characterized by 38 hydrocarbons peaks, belonging to 3 different classes: linear alkanes and mono- and di-methyl-branched alkanes with chain lengths ranging between $\mathrm{C}_{23}$ and $\mathrm{C}_{35}$; with branched alkanes also representing the majority of compounds (GRINSTED et al., 2011). On the other hand, total extract of Tegenaria atrica female, also assessed by GC-MS, is composed of a mixture of 64 saturated hydrocarbons, 7 methyl-esters, 4 acids and 2 unknown compounds, with the majority of compounds being linear alkanes (TRABALON et al., 1996). This difference might be explained by the fact that nestmate recognition in social insects most commonly depends on branched alkanes and alkenes as recognition cues, while linear alkanes have little influence on nestmate recognition (DANI et al., 2001, 2005; VAN ZWEDEN et al., 2009). Thus, branched alkanes might play a more significant role in subsocial spider species or the ones with extended aggregation periods, such as S. lineatus and L. geometricus respectively, than in solitary species with short aggregation period such as T. atrica. Interestingly, a case of subsociality in the genus Latrodectus has been recently described in the Brazilian species Latrodectus cf. curacaviensis (BERTANI et al., 2008).

\section{Conclusions}

According to the results discussed in this study it is possible to infer that there is variation in cuticular chemical composition between the different body parts of adult females of the spider L. geometricus, with the abdomen presenting a greater number of compounds, as well as between adults and juveniles since cuticular chemical profile of all adults' body parts showed greater number of compounds than both juvenile's samples. Also, this is the first study using GC $\times$ GC/qMS to assess cuticular chemical profiles, and according to the results, it can be considered a reliable technique to assess these type of matrices, since it was possible to identify the majority of compounds present in the spider's cuticle, in addition to detect and separate two cases of coelution of compounds. Thus, it can be inferred that the use of this technique is advantageous in assessing species whose cuticular chemical profiles are more complex and therefore could be underestimated by most usual techniques.

\section{Acknowledgment}

The authors thank Universidade Estadual de Mato Grosso do Sul for technical support; Coordenação de Aperfeiçoamento 
de Pessoal de Nível Superior, Fundação de Apoio ao Desenvolvimento do Ensino, Ciência e Tecnologia do Estado de Mato Grosso do Sul for financial support and Conselho Nacional de Desenvolvimento Científico e Tecnológico for: Dr. Claudia Andrea Lima Cardoso scholarship, grant number 311599/2012-5, Dr. Elina Bastos Caramão scholarship, grant number 401352/2014-5 and Dr. William Fernando Antonialli Junior scholarship, grant number 307998/2014-2..

\section{References}

ABALOS JW. The egg-sac in the identification of species of Latrodectus (black-widow spiders). Psyche. 1962;69:268-270.

ANAVA A, LUBIN Y. Presence of gender cues in the web of a widow spider Latrodectus revivensis, and a description of courtship behavior. Bull. Br. Arachnol. Soc. 1993;9:119-122.

ANDRADE MCB, KASUMOVIC MM. Terminal investment strategies and male mate choice: extreme tests of Bateman. Integr. Comp. Biol. 2005;45:838-847.

ANTONIALLI-JUNIOR WF, LIMA SM, ANDRADE LHC, SÚAREZ YR. Comparative study of the cuticular hydrocarbon in queens, workers and males of Ectatomma vizottoi (Hymenoptera, Formicidae) by Fourier transform infrared photoacoustic spectroscopy. Genet. Mol. Res. 2007;6:492-499.

ANTONIALLI-JUNIOR WF, SÚAREZ YR, IZIDA T, ANDRADE LHC, LIMA SM. Intra- and interspecific variation of cuticular hydrocarbon composition in two Ectatomma species (Hymenoptera: Formicidae) based on Fourier transform infrared photoacoustic spectroscopy. Genet. Mol. Res. 2008;7:1-9.

BALA M, SHARMA A. Review of some recent techniques of age determination of blow flies having forensic implications. Egypt. Jour. Forensic. Sci. 2016;6:203-208.

BARUFFALDI L, ANDRADE MCB. Contact pheromones mediate male preference in black widow spiders: avoidance of hungry sexual cannibals? Anim. Behav. 2015;102:25-32.

BARUFFALDI L, COSTA FG. Changes in male sexual responses from silk cues of females at different reproductive states in the wolf spider Schizocosa malitiosa. J. Ethol. 2010;28:75-85.

BARUFFALDI L, COSTA FG. Male reproductive decision is constrained by sex pheromones produced by females. Behaviour. 2014;151:465-477.

BERTANI R, FUKUSHIMA CS, MARTINS R. Sociable widow spiders? Evidence of subsociality in Latrodectus Walckenaer, 1805 (Araneae, Theridiidae). J. Ethol. 2008;26:299-302.

BONAVITA-COUGOURDAN A, THERAULAZ G, BAGNÈRES AG, ROUX M, PRATTE M, PROVOST E, et al. Cuticular hydrocarbons, social organization and ovarian development in a polistine wasp: Polistes dominulus christ. Comp. Biochem. Physiol. B. 1991;100:667-680.

BROWN WV, SPRADBERY JP, LACEY MJ. Changes in the cuticular hydrocarbon composition during development of the social wasp, Vespula germanica (F.) (Hymenoptera: Vespidae). Comp. Biochem. Physiol. B. 1991;99:553-562.

COSTELLO MJ, DAANE KM. Influence of ground cover on spider populations in a table grape vineyard. Ecol. Entomol. 1998;23:33-40.

DANI FR, JONES GR, CORSI S, BEARD R, PRADELLA D, TURILLAZZI S. Nestmate recognition cues in the honey bee: differential importance of cuticular alkanes and alkenes. Chem. Senses. 2005;30:477-489.

DANI FR, JONES GR, DESTRI S, SPENCER SH, TURILLAZZI S. Deciphering the recognition signature within the cuticular chemical profile of paper wasps. Anim. Behav. 2001;62:165-171. 
DEKEIRSSCHIETER J, STEFANUTO P-H, BRASSEUR C, HAUBRUGE E, FOCANT J-F. Enhanced characterization of the smell of death by comprehensive two-dimensional gas chromatography-time-of-flight mass spectrometry (GCxGC-TOFMS). PLoS ONE. 2012;7 e39005.

DONDALE CD, HEGDEKAR BM. The contact sex pheromone of Pardosa lapidicina Emerton (Araneida: Lycosidae). Can. J. Zool. 1973;51:400-401.

EDMONDS DT, VOLLRATH F. The contribution of atmospheric water vapour to the formation and efficiency of spider's capture web. Proc. R. Soc. B. 1992;248:145-148.

FOELIX RF. Biology of spiders. 1st ed. Oxford: Oxford University Press; 2011.

GARB JE, GONZÁLEZ A, GILLESPIE RG. The black widow spider genus Latrodectus (Araneae: theridiidae): phylogeny, biogeography, and invasion history. Mol. Phylogenet. Evol. 2004;31:1127-1142.

GASKETT AC. Spiders sex pheromones: emission, reception, structures, and functions. Biol. Rev. 2007;82:27-48.

GRINSTED L, BILDE T, D'ETTORRE P. Cuticular hydrocarbons as potential kin recognition cues in a subsocial spider. Behav. Ecol. 2011;22:1187-1194.

GUIMARÃES IC, ANTONIALLI-JUNIOR WF, SILVA HM. Aggregation behavior in spiderlings: a strategy for increasing life expectancy in Latrodectus geometricus (Araneae: Theridiidae). Sociobiology 2012;59:463-475.

GUIMARÃES IC, CARDOSO CAL, LIMA SM, ANDRADE LHC, ANTONIALLI-JUNIOR WF. Chemical signals might mediate interactions between females and juveniles of Latrodectus geometricus (Araneae: Theridiidae). Behav. Process. 2016;126:27-35.

ISAACMAN G, WILSON KR, CHAN AWH, WORTON DR, KIMMEL JR, NAH T, et al. Improved resolution of hydrocarbon structures and constitutional isomers in complex mixtures using gas chromatography-vacuum ultraviolet-mass spectrometry. Anal. Chem. 2012;84:2335-2342.

JOHANSSON BG, JONES TM. The role of chemical communication in mate choice. Biol. Rev. 2007;82:265-289.

LEVI HW, LEVI LR, ZIM HS. Spiders and their kin. 1st ed. New York: S.t. Martin's Press, New York; 2001.

LIU Y, MAAS A, WALOSZEK D. Early development of the anterior body region of the grey widow spider Latrodectus geometricus Koch 1841 (Theridiidae,Araneae). Arthropod Struct. Dev. 2009;38:401-416.

LOTZ LN. Revision of the genus Latrodectus (Araneae: Theridiidae) in Africa. Navors. Nas. Mus. 1994;10:1-60.

MA T, XIAO Q, YU Y, WANG C, ZHU C, SUN Z, et al. Analysis of tea geometrid (Ectropis grisescens) pheromone gland extracts using GC-EAD and GC×GC/TOFMS. J. Agric. Food. Chem. 2016;64:3161-3166.

MCCRONE JD. Comparative lethality of several Latrodectus venoms. Toxicon 1964;2:201-203.

MICHELUTTI KB, CARDOSO CAL, ANTONIALLI-JUNIOR WF. Evaluation of chemical signatures in the developmental stages of Mischocyttarus consimilis Zikán (Hymenoptera, Vespidae) employing gas chromatography coupled to mass spectrometry. Rev. Virtual. Quim. 2017;9:535-547.

MONDELLO L, TRANCHIDA PQ, DUGO P, DUGO G. Comprehensive two-dimensional gas chromatographymass spectrometry: a review. Mass. Spectrom. Rev. 2008;27:101-124.

MÜLLER GJ. Black and brown widow spider bites in South Africa. A series of 45 cases. S. Afr. Med. J. 1993;83:399-405.

NEVES EF, ANDRADE LHC, SÚAREZ YR, LIMA SM, ANTONIALLI-JUNIOR WF. Age-related changes in the surface pheromones of the wasp Mischocyttarus consimilis (Hymenoptera: Vespidae). Genet. Mol. Res. 2012;11:1891-1898. 
NEVES EF, MONTAGNA TS, ANDRADE LHC, SÚAREZ YR, LIMA SM, ANTONIALLI-JUNIOR WF. Social parasitism and dynamics of cuticular hydrocarbons in paper wasps of the genus Mischocyttarus. J. Kanas. Entomol. Soc. 2013;86:69-77.

ÖZÇIMEN D, KARAOSMANOĞLU F. Production and characterization of bio-oil and biochar from rapeseed cake. Renew. Energ. 2004;29:779-787.

PASQUET A, TRABALON M, BAGNÈRES AG, LEBORGNE R. Does group closure exist in the social spider Anelosimus eximius? Behavioural and chemical approaches. Insect. Soc. 1997;44:159-169.

POURIÉ G, IBARRA F, FRANCKE W, TRABALON M. Fatty acids mediate aggressive behavior in the spider Tegenaria atrica. Chemoecology. 2005;15:161-166.

POURIÉ G, TRABALON M. Agonistic behaviour of female Tegenaria atrica in the presence of different aged spiderlings. Physiol. Entomol. 1999;24:143-149.

POURIÉ G, TRABALON M. Plasticity of agonistic behaviour in relation to diet and contact signals in experimentally group-living of Tegenaria atrica. Chemoecology. 2001;11:175-181.

PROUVOST O, TRABALON M, PAPKE M, SCHULZ S. Contact sex signals on web and cuticle of Tegenaria atrica (Araneae, Agelenidae). Arch. Insect. Biochem. Physiol. 1999;40:194-202.

RALSTON-HOOPER K, HOPF A, OH C, ZHANG X, ADAMEC J, SEPÚLVEDA MS. Development of GCxGC/ TOF-MS metabolomics for use in ecotoxicological studies with invertebrates. Aquat. Toxicol. 2008;88:48-52.

ROBERTS JA, UETZ GW. Information content of female chemical signals in the wolf spider Schizocosa ocreata: male discrimination of reproductive state and receptivity. Anim. Behav. 2005;70:217-223.

SEGOLI M, ARIELI R, SIERWALD P, HARARI AR, LUBIN Y. Sexual cannibalism in the brown widow spider (Latrodectus geometricus). Ethology 2008;114:279-286.

STOLTZ JA, MCNEIL JN, ANDRADE MCB. Males assess chemical signals to discriminate just-mated females from virgins in red back spiders. Anim. Behav. 2007;74:1669-1674.

TORRES VO, SGUARIZI-ANTONIO D, LIMA SM, ANDRADE LHC, ANTONIALLI-JUNIOR WF. Reproductive status of the social wasp Polistes versicolor (Hymenoptera, Vespidae). Sociobiology. 2014;61:218-224.

TRABALON M, ASSI-BESSÉKON D. Effects of web chemical signatures on intraspecific recognition in a subsocial spider, Coelotes terrestris (Araneae). Anim. Behav. 2008;76:1571-1578.

TRABALON M, BAGNÈRES AG, HARTMANN N, VALLET AM. Changes in cuticular compounds composition during the gregarious period and after dispersal of the young in Tegenaria atrica (Araneae, Agelenidae). Insect. Biochem. Mol. Biol. 1996;26:77-84.

TRABALON M, BAGNÈRES AG, ROLAND C. Contact sex signals in two sympatric spider species, Tegenaria domestica and Tegenaria pagana. J. Chem. Ecol. 1997;23:747-758.

TRABALON M, NIOGRET J, LEGRAND-FROSSI C. Effect of 20-hydroxyecdysone on cannibalism, sexual behavior, and contact sex pheromone in the solitary female spider, Tegenaria atrica. Gen. Comp. Endocr. 2005;144:60-66.

TRABALON M, POURIÉ G, HARTMANN N. Relationship among cannibalism, contact signals, ovarian development and ecdysteroid levels in Tegenaria atrica (Araneae, Agelenidae). Insect. Biochem. Mol. Biol. 1998;28:751-758.

TRABALON M. Agonistic interactions, cuticular and hemolymphatic lipid variations during the foraging period in spider females Brachypelma albopilosa (Theraphosidae). J. Insect. Physiol. 2011;57:735-743. 
UETZ GW, ROBERTS JA. Multisensory cues and multimodal communication in spiders: insights from video/ audio playback studies. Brain. Behav. Evol. 2002;59:222-230.

UHL G. Spider olfaction: attracting, detecting, luring and avoiding. In: NENTWIG W, editor. Spider Ecophysiology. Berlin: Springer-Verlag Berlin Heidelberg; 2013. p. 141-157.

VAN ZWEDEN JS, DREIER S, D'ETTORRE P. Disentangling environmental and heritable nestmate recognition cues in a carpenter ant. J. Insect. Physiol. 2009;55:158-163.

VINCENT LS, VETTER RS, WRENN WJ, KEMPF JK, BERRIAN JE. The brown widow spider Latrodectus geometricus C. L. Koch, 1841, in southern California. Pan-Pac. Entomol. 2008;84:344-349.

WORK RW, MOROSOFF NA. A physico-chemical study of the super contraction of spider major ampullate silk fibers. Text. Res. J. 1982;52:349-356.

WORK RW, YOUNG CT. The amino acid compositions of major and minor ampullate silks of certain orb-web building spiders (Araneae, Araneidae). J. Arachnol. 1987;15:65-80.

WYATT TD. Pheromones and animal behavior: communication by smell and taste. 1st ed. Cambridge: Cambridge University Press; 2003.

\section{Ingrid de Carvalho Guimarães}

Programa de Pós-graduação em Recursos Naturais, Universidade Estadual de Mato Grosso do Sul, Dourados, Mato Grosso do Sul, Brazil - E-mail: guimaraes_ingrid@yahoo.com.br,

Contribuição do autor:

aquisição, análise ou interpretação de dados; redigiu o trabalho ou realizou uma revisão substancial.

\section{Claudia Andrea Lima Cardoso}

Programa de Pós-graduação em Recursos Naturais, Universidade Estadual de Mato Grosso do Sul, Dourados, Mato Grosso do Sul, Brazil - E-mail: claudia@uems.br

Contribuição do autor:

aquisição, análise ou interpretação de dados; redigiu o trabalho ou realizou uma revisão substancial.

\section{Elina Bastos Caramão}

Departamento de Bioquímica Industrial, Universidade Tiradentes, Aracaju, Brazil

Contribuição do autor: E-mail:elina@ufrgs.br

\section{Jaderson Kleveston Schneider}

Instituto de Química, Universidade Federal do Rio Grande do Sul, Porto Alegre, Brazil E-mail:jadersonqme@gmail.com

Contribuição do autor:

aquisição, análise ou interpretação de dados;

\section{William F. Antonialli Junior}

Laboratório de Ecologia Comportamental, Centro de Estudos em Recursos Naturais, Universidade Estadual de Mato Grosso do Sul, Dourados, Brazil- E-mail: williamantonialli@yahoo.com.br

Contribuição do autor:

aquisição, análise ou interpretação de dados; redigiu o trabalho ou realizou uma revisão substancial. 